\title{
LncRNA SRA gene polymorphisms and risk of gynecological pathology development among Ukrainian women with proliferative type of benign breast disease without atypia
}

\author{
I. M. Lukavenko®*B,C, A. V. Kolnoguz ${ }^{(C, D}$, V. Yu. Harbuzova ${ }^{A, E}$, O. V. Ataman ${ }^{F}$
}

Medical Institute of Sumy State University, Ukraine

A - research concept and design; B - collection and/or assembly of data; C - data analysis and interpretation; D - writing the article;

$\mathrm{E}$ - critical revision of the article; $\mathrm{F}$ - final approval of the article

Benign breast disease is a group of all noncancerous mammary lesions with a risk of breast cancer (BC) development. BC is the most common cancer in the world; therefore, it is necessary to find new biomarkers and targets for early diagnosis, treatment, prediction of prognosis and survival. Long non-coding RNA SRA could play this role, thus further studies of its impact on the precancerous lesion pathogenesis are needed.

The aim. To analyze the association between SRA1 rs801460 and rs10463297 SNPs and the occurrence of gynecological pathology among Ukrainian women with the proliferative type of benign breast disease without atypia.

Materials and methods. This study included 115 patients with proliferative type of benign breast disease without atypia: 55 with gynecological pathology and 60 - without it. Polymerase chain reaction-restriction fragment length polymorphism analysis (PCR-RFLP) was used for polymorphism genotyping.

Hematoxylin and eosin, toluidine blue and van Gieson's picrofuchsin methods were applied for staining of sections. Statistical analysis was carried out using Statistical Package for the Social Sciences software (SPSS, version 25.0, Chicago, IL, USA).

Results. Significant differences were found in the rs10463297 frequency of alleles $(P=0.032)$, but not in the rs801460 ( $P>0.05)$, in groups with and without gynecological pathology, while the distribution of both single nucleotide polymorphism (SNPs) genotypes was similar between these groups $(P>0.05)$. Statistically significant association was detected between SRA1 rs 10463297 polymorphism and gynecological pathology occurrence in both dominant $\left(\mathrm{P}_{\mathrm{a}}=0.023 ; \mathrm{OR}_{\mathrm{a}}=2.638,95 \% \mathrm{Cl}=1.145-6.076\right)$ and additive $\left(\mathrm{P}_{\mathrm{a}}=0.034 ; \mathrm{OR}_{\mathrm{a}}=2.489,95 \% \mathrm{Cl}=1.069-5.794\right)$ models of inheritance.

No association was found between SRA1 rs 801460 SNP and gynecological pathology development among Ukrainian women with proliferative type of benign breast disease without atypia $(P>0.05)$.

Conclusions. It was revealed that SRA1 rs10463297 TT carriers had 2.6 times higher risk of gynecological pathology development than $\mathrm{C}$ allele carriers and 2.48 times than TC carriers.

\section{Поліморфізми гена АнPHK SRA та ризик виникнення гінекологічної патології серед українських жінок із проліферативним типом доброякісної дисплазії молочної залози без атипії}

\section{І. М. Аукавенко, А. В. Колногуз, В. Ю. Гарбузова, О. В. Атаман}

Доброякісна дисплазія молочної залози - це група всіх доброякісних захворювань із ризиком розвитку раку молочної залози (РМ3). РМ3 - найбільш поширене онкологічне захворювання у світі, тому важливо знайти нові біомаркери та мішені для ранньої діагностики, лікування, визначення прогнозу та виживання. Довга некодувальна PHK SRA може відіграти цю роль, а отже необхідні дальші дослідження ії впливу на патогенез передракових уражень.

Мета роботи - проаналізувати зв'язок між rs801460 та rs 10463297 поліморфізмами та виникненням гінекологічної патології серед українських жінок із проліфреративним типом доброякісної дисплазії молочної залози без атипії.

Матеріали та методи. У дослідження ввійшли 115 пацієнток із проліферативним типом доброякісної дисплазії молочної залози без атипії: 55 - із гінекологічною патологією та 60 - без неї. Полімеразна ланцюгова реакція з аналізом довжини рестрикційних фрагментів (PCR-RFLP) використана для генотипування поліморфізмів.

Для фрарбування зрізів застосовували гематоксилін, еозин, толуїдиновий синій і пікрофуксин за ван Гізоном. Статистичний аналіз здійснили з використанням програми для статистичного опрацювання даних SPSS 25.0.

Результати. Встановили суттєві відмінності в частоті алелей rs10463297-поліморфізму ( $p=0,032$ ), але не rs801460 $(p>0,05)$ у групах із гінекологічною патологією та без неї. Водночас розподіл генотипів обох поліморфізмів статистично не відрізнявся ( $p>0$ 05). Суттєвий зв'язок виявили між SRA1 rs10463297-поліморфізмом та виникненням гінекологічної патології в домінантній $\left(\mathrm{p}_{\mathrm{a}}=0,023 ; \mathrm{OR}_{\mathrm{a}}=2,638,95 \% \mathrm{Cl}=1,145-6,076\right)$ та адитивній $\left(\mathrm{p}_{\mathrm{a}}=0,034 ; \mathrm{OR}_{\mathrm{a}}=2,489,95 \%\right.$ $\mathrm{Cl}=1,069-5,794)$ моделях.

Не встановлено зв'язку між SRA1 rs801460-поліморфізмом та розвитком цієї патології ( $p$ > 0,05).

Висновки. Виявлено, що носії SRA1 rs10463297 TT-генотипу мають у 2,6 раза вищий ризик розвитку гінекологічної патології, ніж носії С-алеля, та у 2,48 раза - ніж ТС-гетерозиготи.
Key words: breast disease IncRNA, SRA single nucleotide polymorphism.

\section{Zaporozhye} medical journal 2021; 23 (5), 651-655

*E-mail:

i.lukavenko@ med.sumdu.edu.ua
КАючові слова: Аоброякісна Аисплазія молочної за^ози, AHPHK, SRA, ОАНОНУКАЕОТИАНИЙ поліморфізм.

Запорізький медичний журнал. 2021. T. 23, № 5(128).

C. $651-655$ 
Киючевые слова: Аоброкачественная Аисплазия молочной железы, AHPHK, SRA, ОАНОНУКлеОТИАНЫЙ полиморфизм.

Запорожский медицинский журнал. 2021. T. 23, № 5(128). C. $651-655$

\section{Полиморфизмы гена AHPHK SRA и риск развития гинекологической патологии среди украинских женщин с пролиферативным типом доброкачественной дисплазии молочной железы без атипии}

\section{И. М. Аукавенко, А. В. Колногуз, В. Ю. Гарбузова, А. В. Атаман}

Доброкачественная дисплазия молочной железы - это группа всех доброкачественных заболеваний с риском развития рака молочной железы (РМЖ). РМЖ - самое распространённое онкологическое заболевание в мире, поэтому важно найти новые биомаркеры и мишени для ранней диагностики, лечения, определения прогноза и выживаемости. Длинная некодирующая PHK SRA может исполнить эту роль, следовательно нужны дальнейшие исследования её влияния на патогенез предраковых поражений.

Цель работы - проанализировать связь между rs801460 и rs10463197 полиморфизмами и возникновением гинекологической патологии среди украинских женщин с пролиферативным типом доброкачественной дисплазии молочной железы без атипии.

Материалы и методы. В исследование вошли 115 пациенток с пролиферативным типом доброкачественной дисплазии молочной железы без атипии: 55 - с гинекологической патологией и 60 - без нее. Полимеразная цепная реакция с анализом длины рестрикционных фрагментов (PCR-RFLP) использована для генотипирования полиморфизмов. Для окраски срезов использовали гематоксилин и эозин, толуидиновый синий и пикрофуксин по ван Гизону. Статистический анализ проведен с использованием программы для статистической обработки данных SPSS 25.0.

Результаты. Установлены существенные различия в частоте аллелей rs10463297-полиморфизма ( $p=0,032)$, но не rs801460 ( $p>0,05$ ) в группах с гинекологической патологией и без нее. В то время как распределение генотипов обоих полиморфизмов статистически не различалось ( $p>0,05)$.

Существенная связь обнаружена между SRA1 rs10463297-полиморфизмом и возникновением гинекологической патологии в доминантной $\left(\mathrm{p}_{\mathrm{a}}=0.023 ; \mathrm{OR}_{\mathrm{a}}=2,638,95 \% \mathrm{Cl}=1,145-6,076\right)$ и аддитивной $\left(\mathrm{p}_{\mathrm{a}}=0,034 ; \mathrm{OR}_{\mathrm{a}}=2,489,95 \%\right.$ $\mathrm{Cl}=1,069-5,794)$ моделях. Не установлена связь между SRA1 rs801460-полиморфизмом и развитием данной патологии $(\mathrm{p}>0,05)$.

Выводы. Выявлено, что носители SRA1 rs10463297 TT-генотипа имеют в 2,6 раз выше риск развития гинекологической патологии, чем носители С-аллеля, и в 2,48 раз - чем ТС-гетерозиготы.

Since the large-scale genomic projects FANTOM and ENCODE revealed that only $2 \%$ of the human genome is protein-coding and the genome products are predominantly transcribed into non-coding RNAs (ncRNA), a lot of scientists began their efforts to create a catalogue of these RNAs [1,2]. Long non-coding RNAs (IncRNA) were found to have more than 200 nucleotides in length, secondary and three-dimentional structures and regulate the target gene expression [3,4]. A lot of data on the involvement of dysregulated IncRNAs in the oncological processes were presented. Therefore, they can be used as biomarkers and targets to provide the cancer early diagnosis and treatment, predict the prognosis and survival $[2,3]$.

In 1999, the steroid receptor RNA activator (SRA) IncRNA was characterized by Lanz et al. They revealed that SRA specifically transactivates steroid receptors and is encoded by the SRA1 gene [5,6]. A few years ago, they reported SRA overexpression in human tumors of steroid-responsive tissues and SRA-mediated stimulation of proliferation as well as apoptosis in SRA-transgenic mouse models [7].

There is no evidence of an association between any IncRNA and benign breast disease (BBD) development. Given the fact that SRA can coactivate ERa- and Erß-receptors of the breast tissue and stimulate proliferation through the paracrine signaling, it can be assumed that SRA can be involved into the proliferative type of BBD pathogenesis $[8,9]$. In our previous paper, we defined the link between SRA1 rs801460 and rs10463197 single nucleotide polymorphisms (SNP) and proliferative type of BBD with atypia. We have established the positive association between SRA1 rs801460 SNP and this pathology development (not published).

\section{Aim}

To analyze the association between SRA1 rs801460 and rs10463297 SNPs and the occurrence of gynecological pathology among Ukrainian women with the proliferative type of benign breast disease without atypia.

\section{Materials and methods}

Study population. Whole venous blood of 115 Ukrainian females with proliferative type of BBD without atypia was used for the study. The study group included 55 subjects with gynecological pathology (mean age $[ \pm S D] 31.80 \pm 9.13$ ) and the control group - 60 subjects without it (mean age $29.17 \pm 9.27$ ). Gynecological pathology comprised all dyshormonal disorders of reproductive organs. Each patient with proliferative type of BBD was examined by a licensed surgeon (license AG No. 600519) on an outpatient basis and underwent surgical treatment at clinical sites of the Department of Surgery with a Course of Pediatric Surgery and Urology of Sumy Regional Oncology Center. All morphological samples were investigated at the Scientific Center of Pathomorphological Researches of Sumy State University. The Scientific Laboratory of Molecular Genetic Research of Sumy State University performed molecular genetic testing.

The study involved solely individuals with genetic predisposition to the breast diseases, proliferative lesions without atypia and without nonproliferative lesions.

The study design corresponded to the current orders of the Ministry of Health of Ukraine No. 690 from 23.09.2009 and No. 616 from 03.08.2012, the European Convention of Human Rights and Biomedicine, and the World Medical Association Declaration of Helsinki on the Ethical Principles 
for Medical Research Involving Human Subjects. Written informed consents were obtained from all participants.

Genotyping. DNA extraction was done from the whole venous blood of $115 \mathrm{BBD}$ patients using the GeneJET Whole Blood Genomic DNA Purification Kit (Thermo Fisher Scientific, USA). Polymerase chain reaction-restriction fragment length polymorphism analysis (PCR-RFLP) was used for the SRA1 rs801460 and rs10463297 genotyping. The PCR reaction mixture included $5 \mu \mathrm{L}$ of FastDigest Green Buffer (10X) (Thermo Scientific ${ }^{\mathrm{TM}}$, USA), $0.5 \mu \mathrm{L}$ dNTP Mix (10mM of each deoxynucleotide) (Thermo Scientific ${ }^{\mathrm{TM}}$, USA), 0.75U DreamTaq DNA Polymerase ( $5 \mathrm{U} / \mu \mathrm{L}$ ) (Thermo Scientific $^{\mathrm{TM}}$, USA), $0.1 \mu \mathrm{L}$ of each primer, 75-100 ng DNA, and bidistilled water added up to $25 \mu \mathrm{L}$. the next sequences were used the specific primers: forward $-5^{\circ}-\mathrm{GTC}$ CAT TCT GTC TTC ACT TAG-3', reverse - 5'-GGT GGC TCT CCT CTA CTT-3`for rs 10463297; 5'-TTT TTA GTA GAG ACA GGG TTT TGC C-3` and 5'-ACT CTA CGC CAG ACAATA TGC TAT G-3’ for rs801460, respectively. Amplification was conducted using Thermocycler GeneAmp PCR System 2700 (Thermo Fisher Scientific, USA).

The reaction mixture for the restriction included $2 \mathrm{U}$ of restriction enzyme, $0.8 \mu \mathrm{L}$ of 10X Buffer R (Thermo Scientific ${ }^{\mathrm{TM}}$, USA) and bidistilled water added up to $2 \mu \mathrm{L}$. The compound of amplification product $(6 \mu \mathrm{L})$ and reaction mixture $(2 \mu \mathrm{L})$ was incubated at $37^{\circ} \mathrm{C}$ for 20 hours. Nsil restriction enzyme (Thermo Fisher Scientific, USA) was used for SRA1 rs801460 SNP. It cut the amplicon (178bp) into $155 \mathrm{bp}$ and $23 \mathrm{bp}$ fragments in the case of cytosine (C) to thymine $(\mathrm{T})$ replacement at the -5749 th position of the SRA1 gene [10]. The SRA1 rs10463297 SNP restriction analysis was carried out using Eco47I (Thermo Fisher Scientific, USA). The primary amplicon (483bp) was splitted into two fragments of $317 \mathrm{bp}$ and $166 \mathrm{bp}$ by Eco47l in case of $\mathrm{T}$ to $\mathrm{C}$ substitution at the -1440 th position of the SRA1 gene [10].

Horizontal electrophoresis $(10 \mathrm{~V} / \mathrm{cm})$ in $2.5 \%$ agarose gel with the ethidium bromide $(10 \mathrm{mg} / \mathrm{mL})$ addition was applied for restriction fragments separation with further visualization using ultraviolet transillumination.

Histology. The mammary tissue obtained was used for histology. It was fixed in $10 \%$ phosphate buffered formalin for 48 hours and then embedded in paraffin. Paraffin series were sliced at a thickness of 8-10 $\mu \mathrm{m}$ and incubated at $37^{\circ} \mathrm{C}$ for 12 hours with the subsequent deparaffinization. Hematoxylin and eosin, toluidine blue or van Gieson's picrofuchsin were used for sections staining.

Statistical analysis. The informative samples were selected (115 cases) to find the possible association between SRA1 rs801460 and rs10463297 SNPs and gynecological pathology development among patients with proliferative type of BBD without atypia. The statistical analysis was done using Statistical Package for the Social Sciences software (SPSS, version 25.0, Chicago, IL, USA). The distribution for normality was verified according to the Kolmogorov-Smirnov test. Continuous variables were presented as the mean $\pm S D$; categorical variables - as absolute number and percentage value. Chi square $\left(X^{2}\right)$ test was used for the comparison of categorical variables. The mean values for two groups were compared using two-tailed Student's t-test, for three - ANOVA test with subsequent Bonferroni post hoc test. Logistic regression was used to
Table 1. General characteristics of the studied groups

\begin{tabular}{l|l|l|l}
\hline Parameters, units & $\begin{array}{l}\text { With gynecological } \\
\text { pathology }(\mathbf{n}=\mathbf{5 5})\end{array}$ & $\begin{array}{l}\text { Without gynecological } \\
\text { pathology }(\mathbf{n}=\mathbf{6 0})\end{array}$ & $\mathbf{P}$ \\
\hline Age, years & $31.80 \pm 9.13$ & $29.17 \pm 9.27$ & 0.785 \\
\hline Weight, $\mathrm{kg}$ & $59.91 \pm 11.30$ & $58.33 \pm 8.99$ & 0.281 \\
\hline Height, $\mathrm{cm}$ & $166.53 \pm 6.48$ & $166.62 \pm 7.15$ & 0.913 \\
\hline $\mathrm{BMl}, \mathrm{kg} / \mathrm{m}^{2}$ & $21.57 \pm 3.63$ & $20.98 \pm 2.63$ & 0.097 \\
\hline $\begin{array}{l}\text { Height of the glandular part } \\
\text { of the breast, mm }\end{array}$ & $14.80 \pm 3.73$ & $15.87 \pm 4.42$ & 0.446 \\
\hline $\begin{array}{l}\text { Height of the fibroglandular part } \\
\text { of the breast, mm }\end{array}$ & $18.93 \pm 4.33$ & $19.78 \pm 4.37$ & 0.785 \\
\hline $\begin{array}{l}\text { Age at menarche, years } \\
\text { Abortions, } \mathrm{n}(\%)\end{array}$ & $13.42 \pm 1.62$ & $13.48 \pm 1.38$ & 0.217 \\
\hline $\begin{array}{l}\text { Oral contraceptive intake, } \mathrm{n}(\%) \\
\text { Smokers, } \mathrm{n}(\%)\end{array}$ & $24(43.6)$ & $18(30.0)$ & 0.129 \\
\hline
\end{tabular}

Categorical variables were compared by $\mathrm{X}^{2}$ test, continuous variables - by t-test.

estimate the odds ratio (OR) and $95 \%$ confidence interval (Cl) for the four models of inheritance: dominant, recessive, over-dominant and additive. The adjustments for age, BMI, oral contraceptives intake, abortions and smoking were used for multivariable logistic regression. AP value $<0.05$ was considered as significant.

\section{Results}

The general characteristics of the study groups are shown in Table 1. The studied groups were matched by mean age, weight, height, BMI, height of the glandular and fibroglandular parts of the breast, age at menarche, abortions and smoking $(P>0.05)$. The significant difference was found only in oral contraceptives intake $(P=0.038)$.

Table 2 contains the results of the SRA1 rs 801460 and rs10463297 alleles and genotype distribution. The frequency of SRA1 rs10463297 alleles, but not genotypes $(P=0.052)$, in patients with gynecological pathology significantly differed from the group without it $(P=0.032)$, while the distribution of SRA1 rs801460 alleles and genotypes was similar between these groups $(P>0.05)$.

The results of SRA1 rs801460 and rs10463297 genotypic association with gynecological pathology development among women with proliferative type of BBD without atypia are presented in Table 3. Statistically significant association was found between SRA1 rs10463297 polymorphism in both dominant $\left(P_{c}=0.024\right.$; $\left.\mathrm{OR}_{\mathrm{c}}=2.437,95 \% \mathrm{Cl}=1.127-5.271\right)$ and additive $\left(P_{c}=0.040 ; O_{c}=2.277,95 \% \mathrm{Cl}=1.037-4.998\right)$ inheritance models, as well as after adjustment for age, body mass index, abortions, oral contraceptive intake and smoking (dominant $\left(\mathrm{P}_{\mathrm{a}}=0.023 ; \mathrm{OR}_{\mathrm{a}}=2.638,95 \%\right.$ $\mathrm{Cl}=1.145-6.076)$, additive $\left(\mathrm{P}_{\mathrm{a}}=0.034 ; \mathrm{OR}_{\mathrm{a}}=2.489\right.$, $95 \% \mathrm{Cl}=1.069-5.794)$ models). There was no association between rs 801460 and gynecological pathology occurrence $(P>0.05)$.

\section{Discussion}

BBD is a group of all noncancerous mammary lesions. It is classified into nonproliferative type, proliferative type with and without atypia. The latter two have a high risk of breast cancer (BC) development [11]. BC is the most common cancer in the world; therefore, it is very important 
Table 2. Distributions of genotypes and alleles in compared groups

\begin{tabular}{|c|c|c|c|c|c|c|c|c|}
\hline \multirow[t]{2}{*}{ Gene } & \multirow[t]{2}{*}{ SNP } & & \multicolumn{2}{|c|}{$\begin{array}{l}\text { With gynecological } \\
\text { pathology }\end{array}$} & \multicolumn{2}{|c|}{$\begin{array}{l}\text { Without gynecolo- } \\
\text { gical pathology }\end{array}$} & \multirow[t]{2}{*}{$x^{2}$} & \multirow[t]{2}{*}{$\mathbf{P}$} \\
\hline & & & $n$ & $\%$ & $n$ & $\%$ & & \\
\hline \multirow[t]{14}{*}{ SRA1 } & \multirow[t]{7}{*}{ rs801460 } & \multicolumn{5}{|c|}{ Genotypes } & \multirow{4}{*}{2.731} & \multirow{4}{*}{0.255} \\
\hline & & $\mathrm{CC}$ & 15 & 27.3 & 24 & 40.0 & & \\
\hline & & CT & 34 & 61.8 & 28 & 46.7 & & \\
\hline & & TT & 6 & 10.9 & 8 & 13.3 & & \\
\hline & & \multicolumn{5}{|c|}{ Alleles } & \multirow{3}{*}{0.639} & \multirow{3}{*}{0.424} \\
\hline & & C & 64 & 58.2 & 76 & 63.3 & & \\
\hline & & $\mathrm{T}$ & 46 & 41.8 & 44 & 36.7 & & \\
\hline & \multirow[t]{7}{*}{ rs10463297 } & \multicolumn{5}{|c|}{ Genotypes } & \multirow{4}{*}{5.921} & \multirow{4}{*}{0.052} \\
\hline & & $\mathrm{TT}$ & 16 & 29.1 & 30 & 50.0 & & \\
\hline & & TC & 34 & 61.8 & 28 & 46.7 & & \\
\hline & & $\mathrm{CC}$ & 5 & 9.1 & 2 & 3.3 & & \\
\hline & & \multicolumn{5}{|c|}{ Alleles } & \multirow{3}{*}{4.612} & \multirow{3}{*}{0.032} \\
\hline & & $\mathrm{T}$ & 66 & 60.0 & 88 & 73.3 & & \\
\hline & & C & 44 & 40.0 & 32 & 26.7 & & \\
\hline
\end{tabular}

SNP: single nucleotide polymorphism; categorical variables were compared by $\chi^{2}$ test

Table 3. Analysis of SRA1 rs801460 and rs10463297 genotypic association with gynecological pathology development among women with proliferative type of BBD without atypia

\begin{tabular}{|c|c|c|c|c|c|}
\hline SNP & Model & $\mathbf{P}_{c}$ & $\mathrm{OR}_{\mathrm{c}}(95 \% \mathrm{Cl})$ & $\mathbf{P}_{\mathrm{a}}$ & $\mathrm{OR}_{\mathrm{a}}(95 \% \mathrm{Cl})$ \\
\hline \multirow[t]{5}{*}{ rs801460 } & Dominant & 0.152 & $1.778(0.809-3.904)$ & 0.093 & $2.088(0.884-4.928)$ \\
\hline & Recessive & 0.692 & $0.796(0.258-2.459)$ & 0.782 & $0.843(0.253-2.811)$ \\
\hline & Over-dominant & 0.105 & $1.850(0.880-3.893)$ & 0.081 & $2.012(0.917-4.417)$ \\
\hline & Additive $^{1}$ & 0.111 & $1.943(0.859-4.395)$ & 0.073 & $2.237(0.927-5.399)$ \\
\hline & & 0.773 & $1.200(0.347-4.145)$ & 0.590 & $1.450(0.376-5.598)$ \\
\hline \multirow[t]{5}{*}{ rs10463297 } & Dominant & 0.024 & $2.437(1.127-5.271)$ & 0.023 & $2.638(1.145-6.076)$ \\
\hline & Recessive & 0.215 & $2.900(0.539-15.605)$ & 0.234 & $2.923(0.500-17.093)$ \\
\hline & Over-dominant & 0.105 & $1.850(0.880-3.893)$ & 0.102 & $1.919(0.878-4.192)$ \\
\hline & Additive $^{1}$ & 0.040 & $2.277(1.037-4.998)$ & 0.034 & $2.489(1.069-5.794)$ \\
\hline & & 0.083 & $4.687(0.816-26.934)$ & 0.076 & $5.417(0.838-35.002)$ \\
\hline
\end{tabular}

SNP: single nucleotide polymorphism; Cl: confidence interval; Pc: crude P value; ORc: crude odds ratio; $P a: P$ value adjusted for age, body mass index, abortions, oral contraceptive intake and smoking: ORa: adjusted odds ratio. ${ }^{1}$ Upper row in the additive inheritance model - comparison between Aa and AA genotypes; lower row - between aa and AA genotypes.

to find new biomarkers and targets for early diagnosis, treatment, prediction of prognosis and survival $[12,13]$. In our previous paper, we found the positive link between SRA1 rs801460 SNP and proliferative type of BBD with atypia development (not published). This paper considered the association between SRA1 rs801460 and rs 10463297 polymorphisms and the occurrence of gynecological pathology among women with the proliferative type of BBD without atypia.

A few papers reported on the SRA1 polymorphisms. Rui Yan et al. studied the association between SRA1 rs 801460 and rs10463297 SNPs and BC development. They found that rs 10463297 TC genotype increased BC risk compared to the $\mathrm{CC}$ genotype. However, they did not reveal a significant link between SRA1 rs801460 SNP and BC development [14]. At the same time, Jifan Tan et al. disclosed that the SRA1 rs10463297 polymorphism was associated with polycystic ovary syndrome susceptibility [15].

Our results have shown significant differences in the rs10463297 frequency of alleles in groups with and without gynecological pathology. Statistically significant association has been found between SRA1 rs10463297 polymorphism and gynecological pathology occurrence in dominant and additive inheritance models. Consequently,
TT-carriers had 2.6 times higher risk of gynecological pathology development than C-allele carriers; at the same time, they had 2.48 times higher risk of gynecological pathology occurrence than TC genotype carriers.

\section{Conclusions}

1. The frequency of SRA1 rs10463297 alleles in patients with gynecological pathology is significantly different from the group without it $(P=0.032)$.

2. Statistically significant association between SRA1 rs10463297 polymorphism and gynecological pathology occurrence in both dominant and additive models of inheritance $(P>0.05)$ has been found.

3. No association has been detected between SRA1 rs801460 SNP and gynecological pathology development $(P>0.05)$.

4. SRA1 rs 10463297 TT carriers have 2.6 times higher risk of gynecological pathology development than $\mathrm{C}$ allele carriers and 2.48 times compared with TC carriers.

Prospects for future research. Further studies are necessary to expand the comparison groups and confirm results. Moreover, the association analysis between other SRA1 SNPs and proliferative type of BBD development are needed for better understanding the IncRNA SRA role in BBD.

Conflicts of interest: authors have no conflict of interest to declare. Конфмікт інтересів: віАсутній.

Надійшла Ао редакції / Received: 29.04.2021

Після Аоопрацювання / Revised: 27.05.2021

Прийнято Ао Аруку / Accepted: 16.06.2021

Information about authors:

Lukavenko I. M., MD, PhD, Assistant of the Department of

Surgery, Traumatology, Orthopedics and Phthisiology, Sumy State University, Ukraine.

ORCID ID: 0000-0003-4789-215X

Kolnoguz A. V., medical student, Sumy State University, Ukraine. ORCID ID: 0000-0002-3964-0414

Harbuzova V. Yu., PhD, DSc, Professor of the Department of Physiology and Pathophysiology with Medical Biology Course, Sumy State University, Ukraine.

ORCID ID: 0000-0001-7183-6997.

Ataman 0. V., MD, PhD, DSc, Professor, Head of the Department of Physiology and Pathophysiology with Medical Biology Course, Sumy State University, Ukraine.

ORCID ID: 0000-0002-1941-740X

\section{Відомості про авторів:}

Лукавенко І. М., канА. МеА. наук, асистент каф. хірургії, травматології, ортопеАії та фтизіатрії, Сумський Аержавний університет, Україна.

Колногуз А. В., студентка, Медичний інститут, Сумський Аержавний університет, Україна.

Гарбузова В. Ю., А-р біол. наук, професор каф. фізіології і патофізіології з курсом медичної біології, Сумський Аержавний університет, Україна.

Атаман О. В., А-р меА. наук, професор, зав. каф. фізіології і патофізіології з курсом медичної біології, Сумський державний університет, Україна.

\section{Сведения об авторах:}

Аукавенко И. М., канА. меА. наук, ассистент каф. хирургии, травматологии, ортопедии и фтизиатрии, Сумский государственный университет, Украина. 
Колногуз А. В., стуАентка, Медицинский институт, Сумский государственный университет, Украина.

Гарбузова В. Ю., А-р биол. наук, профессор каф. физиологии и патофизиологии с курсом меАицинской биологии, Сумский государственный университет, Украина.

Атаман А. В., А-р меА. наук, профессор, зав. каф. физиологии и патофизиологии с курсом медицинской биологии, Сумский государственный университет, Украина.

\section{References}

[1] Djebali, S., Davis, C. A., Merkel, A., Dobin, A., Lassmann, T., Mortazavi, A., Tanzer, A., Lagarde, J., Lin, W., Schlesinger, F., Xue, C., Marinov, G. K., Khatun, J., Williams, B. A., Zaleski, C., Rozowsky, J., Röder, M., Kokocinski, F., Abdelhamid, R. F., Alioto, T., ... Gingeras, T. R. (2012). Landscape of transcription in human cells. Nature, 489(7414), 101-108. https://doi.org/10.1038/nature11233

[2] Sanchez Calle, A., Kawamura, Y., Yamamoto, Y., Takeshita, F., \& Ochiya, T. (2018). Emerging roles of long non-coding RNA in cancer. Cancer Science, 109(7), 2093-2100. https://doi.org/10.1111/cas.13642

[3] Chi, Y., Wang, D., Wang, J., Yu, W., \& Yang, J. (2019). Long Non-Coding RNA in the Pathogenesis of Cancers. Cells, 8(9), Article 1015. https:// doi.org/10.3390/cells8091015

[4] Anastasiadou, E., Jacob, L. S., \& Slack, F. J. (2018). Non-coding RNA networks in cancer. Nature Reviews Cancer, 18(1), 5-18. https://doi. org/10.1038/nrc.2017.99

[5] Lanz, R. B., McKenna, N. J., Onate, S. A., Albrecht, U., Wong, J., Tsai, S. Y., Tsai, M. J., \& O'Malley, B. W. (1999). A Steroid Receptor Coactivator, SRA, Functions as an RNA and Is Present in an SRC-1 Complex. Cell, 97(1), 17-27. https://doi.org/10.1016/s0092-8674(00)80711-4

[6] Leygue, E. (2007). Steroid Receptor RNA Activator (SRA1): Unusual Bifaceted Gene Products with Suspected Relevance to Breast Cancer. Nuclear Receptor Signaling, 5(1), Article e006. https://doi.org/10.1621/ nrs.05006

[7] Lanz, R. B., Chua, S. S., Barron, N., Söder, B. M., DeMayo, F., \& O'Malley, B. W. (2003). Steroid Receptor RNAActivator Stimulates Proliferation as Well as Apoptosis In Vivo. Molecular and Cellular Biology, 23(20), 7163-7176. https://doi.org/10.1128/MCB.23.20.7163-7176.2003

[8] Clarke, R. B. (2004). Human breast cell proliferation and its relationship to steroid receptor expression. Climacteric, 7(2), 129-137. https://doi. org/10.1080/13697130410001713751

[9] Sheng, L., Ye, L., Zhang, D., Cawthorn, W. P., \& Xu, B. (2018). New Insights Into the Long Non-coding RNA SRA: Physiological Functions and Mechanisms of Action. Frontiers in Medicine, 5, Article 244. https:// doi.org/10.3389/fmed.2018.00244

[10] Sherry, S. T., Ward, M. H., Kholodov, M., Baker, J., Phan, L., Smigielski, E. M. \& Sirotkin, K. (2001). dbSNP: the NCBI database of genetic variation. Nucleic Acids Research, 29(1), 308-311. https://doi. org/10.1093/nar/29.1.308

[11] Calhoun, B. C., Grobmyer, S. R., \& Simpson, J. F. (2018). 8 - Benign, High-Risk, and Premalignant Lesions of the Breast. In K. I. Bland, E. M. Copeland, V. S. Klimberg \& W. J. Gradishar (Eds.), The Breast (pp. 116129.e3). Elsevier. https://doi.org/10.1016/b978-0-323-35955-9.00008-8

[12] International Agency for Research on Cancer. (n.d.). CANCER TODAY Data visualization tools for exploring the global cancer burden in 2020. https://gco.iarc.fr/today/home

[13] Sasaki, J., Geletzke, A., Kass, R. B., Klimberg, V. S., Copeland, E. M., \& Bland, K. I. (2018). 5 - Etiology and Management of Benign Breast Disease. In K. I. Bland, E. M. Copeland, V. S. Klimberg \& W. J. Gradishar (Eds.), The Breast (pp. 79-92.e5). Elsevier. https://doi.org/10.1016/ b978-0-323-35955-9.00005-2

[14] Yan, R., Wang, K., Peng, R., Wang, S., Cao, J., Wang, P., \& Song, C. (2016). Genetic variants in IncRNA SRA and risk of breast cancer. Oncotarget, 7(16), 22486-22496. https://doi.org/10.18632/ oncotarget.7995

[15] Tan, J., Hao, X., Zhao, T., Ying, J., Li, T., \& Cheng, L. (2020). Association between long-chain non-coding RNA SRA1 gene single-nucleotide polymorphism and polycystic ovary syndrome susceptibility. Journal of Assisted Reproduction and Genetics, 37(10), 2513-2523. https:/l doi.org/10.1007/s10815-020-01922-3 